\title{
XII. The theory of vegetable physiology of $M$. Aubert du Petit Thouars; or of the increase of plants by means of buds, or fixed embryos
}

John Lindley Esq.

To cite this article: John Lindley Esq. (1824) XII. The theory of vegetable physiology of M. Aubert du Petit Thouars; or of the increase of plants by means of buds, or fixed embryos, Philosophical Magazine Series 1, 64:316, 81-83, DOI: 10.1080/14786442408644559

To link to this article: http://dx.doi.org/10.1080/14786442408644559

曲 Published online: 29 Jul 2009.

Submit your article to this journal $\pi$

Џll Article views: 2

Q View related articles $\sqsubset$ 


\title{
PHILOSOPHICAL MAGAZINE AND JOURNAL.
}

\author{
$31^{\text {st }} A U G U S T$ 1824.
}

XII. The Theory of Vegretable Physiology of $M$. Aubert Du Petit Thounars; or of the Increase of Plants by means of Buds, or fexed Embryos. By JoH N Lindery, Esq.

To the Editors of the Philosophical Magazine and Journal.

Gentlemen,

WISH to direct the attention of naturalists in this country to a curious theory of vegetable physiology which arose in France several years since, but which has not yet attracted notice here. The author, M. du Petit Thouars, is equally remarkable for the originality of his opinions, and for the dexterity and ingenuity with which he supports them. They are scattered over many separate works, and have been published piecemeal and at long intervals of time; so that even in his own country, where his works are best known, few persons can be found who are acquainted with the precise nature of his theory, or who will take the trouble to consider the plain propositions upon which it is supported, divested of their discursive and deeply metaphysical illustrations.

This theory has always appeared to me to be a most remarkable explanation of most of the phænomena of vegetable increase; and I have for a long time hoped that some notice would have been taken of it in those of our elementary works which are devoted to the subject of vegetable physiology.

Whether the opinions of M. du Petit Thouars are founded on true or false reasoning, it is not necessary now to inquire. They are at least the opinions of a man of high reputation as a botanist and philosopher; they have never been contradicted by any writer of talent, and from their peculiarity and ingenuity are certainly deserving of attention. I therefore have subjoined to this communication the principal propositions connected with the theory, extracter from the latest publication of the author, in which they have all been collected. If it should appear that sufficient interest exists among botanists in this country to induce you to occupy the pages of your

Vol. 64. No. 316. Ang. $182 \%$. L Journal 
Journal with a continuation of the subject, I will at future opportunities arrange under their respective heads the principal facts and arguments upon which the theory is supported.

I am, gentlemen, yours truly,

Turnham Green, July $26,1824$.

JoHN LiNDLEY.

1. The BUD is the first visible moveable point of vegetation.

One exists at the axilla of every leaf.

It is manifest in the greater number of dicotyledonous plants and of grasses.

It is latent in monocotyledonous plants, in which it exists only as a vital point.

The leaf therefore is to the bud what the flower is to the fruit and seed.

2. The bud is at first supported by the juices contained in the utricles of the interior vegetable substance or parenchyma. This is the operation by which the parenchyma is reduced to the state of pith.

That part is therefore analogous to the cotyledon of the SEED Or SEMINAL FMBRYO.

3. As soon as the bud is formed, it is subject to two general movements.

The one is a motion upwards, or an aërial motion;

The other is a motion downwards, or a terrestrial motion.

From the first proceed the embryos of leaves,

Analogous to which is the plumule;

From the second proceeds the formation of the new fibres of the wood or bark,

Analogous to which is the radicle.

4. Each of these fibres is formed at the expense of the cambium, or of the sap produced by the first fibres and deposited between the wood and bark.

The fibres carry downwards the matter necessary for their own elongation,

Which matter is the descending sap.

5. The development of the bud consists in the aërial or leafy elongation of these fibres;

Each of which, attracted by the leafy extremity, carries upwards with it the matter necessary for its own elongation,

Which matter is the ascending sap.

6. From this sap are formed two general substances, the woody and the parenchymatous. (Which were long ago recognised by (Grew.)

The woody is disposed in fibres which undergo no change. 
The parenchymatous appears formed, in the outset, of detached particles which unite and form utricles; so that it assists in the process of increase in every direction. This is the only substance which is susceptible of a green colour.

7. The sap is the food of plants.

It is pumped up, in the form of moisture, by the roots, and it becomes exposed to the atmosphere in the leaves.

In the first instance it has a common use; but finally it receives a particular destination according to the kinds of plants and their parts.

It is only carried to the points where it is wanted, so that there is no universal circulation.

Being composed, principally, of the two general substances of which mention has been made, the woody and the parenchymatous, as soon as one of these is employed in the process of vegetation, it is necessary that the other should be disengaged and deposited in the vicinity; so that the application of one substance is the separation of the other.

XIII. On the Extraction of Selenium from the Residutm of the Sulphuric Acid Works of Lulkawitz in Bohemia ; and on the Cause of the Odour of Tellurium. By Professor Schouz, of the Polytechnic Institution of Vienna.*

IN the winter of the years 1821-2, I examined the thick matter which collects in the leaden chambers of the Auersperg manufactory of sulphuric acid at Lukawitz in Bohemia, and which, from its gray colour inclining to red, had excited the attention of M. Schrattenbach, the director of the works, and a very active man, who delights in the promotion of the natural sciences. A few experiments upon it with chemical tests immediately showed that it contained selenium, of which I have now extracted from it several ounces in its purest form. As this residuum was not of such a compound nature as that of the Gripsholm Works, from which Berzelius first extracted selenium, I was enabled to make use of a process much more simple than the one he adopted to obtain that body. The substance was introduced into a tubulated retor;, with muriatic acid and a little nitric acid; and nitric acid being added from time to time, was evaporated nearly to dryness on a sandheat. It was now repeatedly lixiviated with boiling water; the solution filtered, concentrated by evaporation, anc? mixed with a solution of sulphite of ammonia, which had been

* From Schweigger's Journal fuir Chemie, \&c. N. R. band viii, p. 231. 